\title{
Terra Preta Properties in Northwestern Amazonia (Colombia)
}

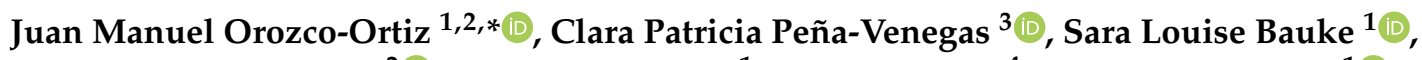 \\ Christian Borgemeister ${ }^{2}{ }^{(}$, Ramona Mörchen ${ }^{1}$, Eva Lehndorff ${ }^{4}$ and Wulf Amelung ${ }^{1}$ (i) \\ 1 Institute of Crop Science and Resource Conservation (INRES), Soil Science and Soil Ecology, \\ University of Bonn, 53115 Bonn, Germany; sarabauke@uni-bonn.de (S.L.B.); \\ ramona.moerchen@uni-bonn.de (R.M.); wulf.amelung@uni-bonn.de (W.A.) \\ 2 Center for Development Research (ZEF), University of Bonn, 53113 Bonn, Germany; cb@uni-bonn.de \\ 3 Instituto Amazónico de Investigaciones Científicas (SINCHI), Leticia 910001, Colombia; cpena@sinchi.org.co \\ 4 Soil Ecology, Bayreuth University, 95448 Bayreuth, Germany; eva.lehndorff@uni-bayreuth.de \\ * Correspondence: orozco.ortiz.juan@gmail.com
}

Citation: Orozco-Ortiz, J.M.; Peña-Venegas, C.P.; Bauke, S.L.; Borgemeister, C.; Mörchen, R.; Lehndorff, E.; Amelung, W. Terra Preta Properties in Northwestern Amazonia (Colombia). Sustainability 2021, 13, 7088. https://doi.org/ $10.3390 /$ su13137088

Academic Editors:

Vasileios Tzanakakis,

Theocharis Chatzistathis and Jose Navarro Pedreño

Received: 1 May 2021

Accepted: 18 June 2021

Published: 24 June 2021

Publisher's Note: MDPI stays neutral with regard to jurisdictional claims in published maps and institutional affiliations.

Copyright: (c) 2021 by the authors. Licensee MDPI, Basel, Switzerland. This article is an open access article distributed under the terms and conditions of the Creative Commons Attribution (CC BY) license (https:/ / creativecommons.org/licenses/by/ $4.0 /)$.

\begin{abstract}
Whereas many researchers still approach Terra Preta (TP) as a soil category, new evidence suggests that TP refers to a directional grading of soil property changes (i.e., color, $\mathrm{pH}$, nutrients, etc.) within human-made soils, originating from human activities in pre-Columbian times. Currently, most TP research focuses on the Brazilian part of the Amazon basin, but only little information is available on TP soils in the Colombian Amazon. Here, we sampled four TP and surrounding soils in the Colombian Amazon region at different soil depths and analyzed them for (i) general soil properties such as color, $\mathrm{pH}$ and texture, (ii) soil organic carbon and black carbon (BC) contents, the latter using benzene polycarboxylic acids as molecular marker, (iii) phosphorus availability based on sequential fractionation, and (iv) microbial residue contents using amino sugars. Our data from Colombia's middle Caquetá River and Leticia confirmed that SOC, BC, and total P were present in significantly higher concentrations in the TP areas than the surrounding soils, while $\mathrm{pH}$ values and microbial residue contents were unchanged. The enrichment of $\mathrm{P}$ forms comprised both easily extractable and stable P pools, which both dominated to a different degree, both in TP and adjacent soils. The different degree of SOC, BC and P enrichment suggests different amounts of waste disposal by the ancient populations at different TP sites, now warranting further research for reconstructing ancient population sizes from TP chemical analyses.
\end{abstract}

Keywords: amazonian anthrosols; tropical soils; Terra Preta; soil formation; phosphorus; black carbon

\section{Introduction}

Within a total area of about 7 million square kilometers, only a small area of the Amazon basin has been considered for the influence of past human occupation [1]. With increasing evidence of human impacts on Amazonian ecosystems [2,3], proof of preColumbian human occupation is becoming more relevant to better understand and learn from ancient cultures' more sustainable ecosystem management. In this regard, the improvement of low-nutrient, acidic soils in the Amazon has been a "trademark" of Amazon ancient civilizations that could tackle different contemporary and future problems $[4,5]$.

These fertile anthropogenic soils have been called Amazonian Dark Earths (ADE), Archaeological Black Earths (ABE), or simply Terra Preta (TP), which translates to "Black Earth" from Portuguese [6,7]. The TP soils show specific characteristics that distinguish them from typical adjacent (ADJ) soils. The presence of abundant ceramic sherds, darker color, and remains of animal and plant materials indicate waste disposal activities [8,9] and, therefore, the main formation processes involved should be comparable for all TP sites. However, TP sites across the Amazon are associated with different pre-Columbian cultures [10-12], suggesting that the spatial distribution and specific habits of each of these cultures have affected TP formation [13-15]. Therefore, to some extent, TP properties are generally different between and within sites [16]. 
Differences in TP properties can be found within countries and regions. In many cases, high TP fertility has been attributed to high contents of phosphorus (P) and organic matter, including charred remains, as well as to elevated $\mathrm{pH}$ values reducing aluminum (Al) toxicity [17-19]. Still, the variation in these properties between sites has received less attention. Most of the studies about TP formation processes have been carried out based on the analysis of soil samples collected in the Brazilian part of the Amazon [15,20], yet important TP sites are also found in Colombia [21-24], where the Amazon region covers about $40 \%$ of the country's territory [25]. In Colombia, special attention has been paid to Anthrosols in the middle Caquetá River and, near Leticia, the capital of Colombia's Amazon department $[21,23,26]$.

Inferences about the formation of TP soils in Colombia have been based upon the study of archaeological remains (i.e., ceramic sherds, phytoliths), reconstruction of historical events through contemporary indigenous knowledge [27], and/or physicochemical soil properties $[23,28]$. Eden and colleagues (1984) concluded that there was no evidence to assume that the TP characteristics were originally the result of agricultural activity. Subsequent studies in Colombia suggested that TP soils enabled the transformation of agricultural systems [22], yet whether agriculture was needed in the pre-Columbian Amazon basin is still debated [29]. For instance, the presence of TPs in the fertile floodplains of the Brazilian Amazon, where soil improvement is not required, suggests that TP soils were not originally created for agricultural purposes [30]. Hence, unintentional anthropogenic formation of TPs is still a possibility.

Schmidt et al. [31] reported that TPs in Brazil occurred in a widespread pattern of mounds found in and around settlements where indigenous populations disposed of waste. The middens presented high $\mathrm{P}$ and soil organic carbon (SOC) contents and showed elevated $\mathrm{pH}$ values. Although Colombian indigenous knowledge indicated that certainly also areas with TP in Colombia were settlement spaces [32], it remains to be confirmed if discarded charred material and organic waste were linked to the formation of Colombian TP soils. Clearly, the accumulation of $\mathrm{P}$ is of paramount interest because it is abundant in TP soils but generally deficient in the surrounding, highly weathered soils of the Amazon Basin [33,34]. Souza et al. [34] reported that the dominance of Calcium-bound P forms (CaP) found in Brazil's western Amazon region depended on the original soil texture where TP originated, although other researchers pointed out that P in TP soils might not be present in the most available $\mathrm{P}$ forms but in more stable pools [34,35]. In Colombia, TP soils with abundant ceramics and dark coloration remain very acidic [26], which suggests that the distribution of P into different fractions may vary from Brazilian TP. Eden et al. [21] reported lower levels of available P in TP soils excavated at the riparian sites of the Caquetá basin in Colombia, compared with the higher concentrations of available P forms found in Brazil by [36].

Sequential P extractions may be used to differentiate between $\mathrm{P}$ pools of different bioavailability, which can be related to specific sources such as biogenic apatite [35], to P transformations [37] or even soil formation processes [15,20,34]. In contrast, information on the origin of soil organic matter (SOM) can be obtained by the analyses of so-called biomarkers, i.e., of compounds that are specific to cell residues of its source organisms [38,39]. Biomarker analyses have thus become standard in TP research [40-43], proving the presence of feces and organic waste remains from steroidal compounds [44] as well as of charred remains [45-47]. The latter evidence relied on a methodology that combusts char residues with hot nitric acid to benzene polycarboxylic acids [48-50]. Compared to other methods, this procedure has the extra advantage that the ratio of penta- to hexabenzene carboxylic acid (B5CA:B6CA) also informs on the quality of the char residues, particularly on its degree of condensation and thus on charring temperature [51,52]. Other studies reported elevated amino sugars contents in TP soils $[17,44,53]$. These marker substances generally point to fungal and bacterial necromass [54,55] as common for a high degree of microbial SOM transformation [56]. Glucosamine might in principle also originate from the chitin of arthropods, but unless specifically abundant, their abundance is usually much lower as 
compared to that of fungal chitin [39]. Biomarker analyses are still lacking for Colombian TP soils and may thus help to understand inter-site variability as well as similarities or differentiation from Brazilian TP soils.

This study was designed to contribute to a better understanding of the properties and origin of TP soils in Colombia. Hence, we sampled TP sites and surrounding soils at different ecological settings [21,23,28] at the Caquetá River (Araracuara (AR), Villa Azul (VA) and Peña Roja (PR)) as well as near the municipality of Leticia (Takana (TA)) (Figure 1).

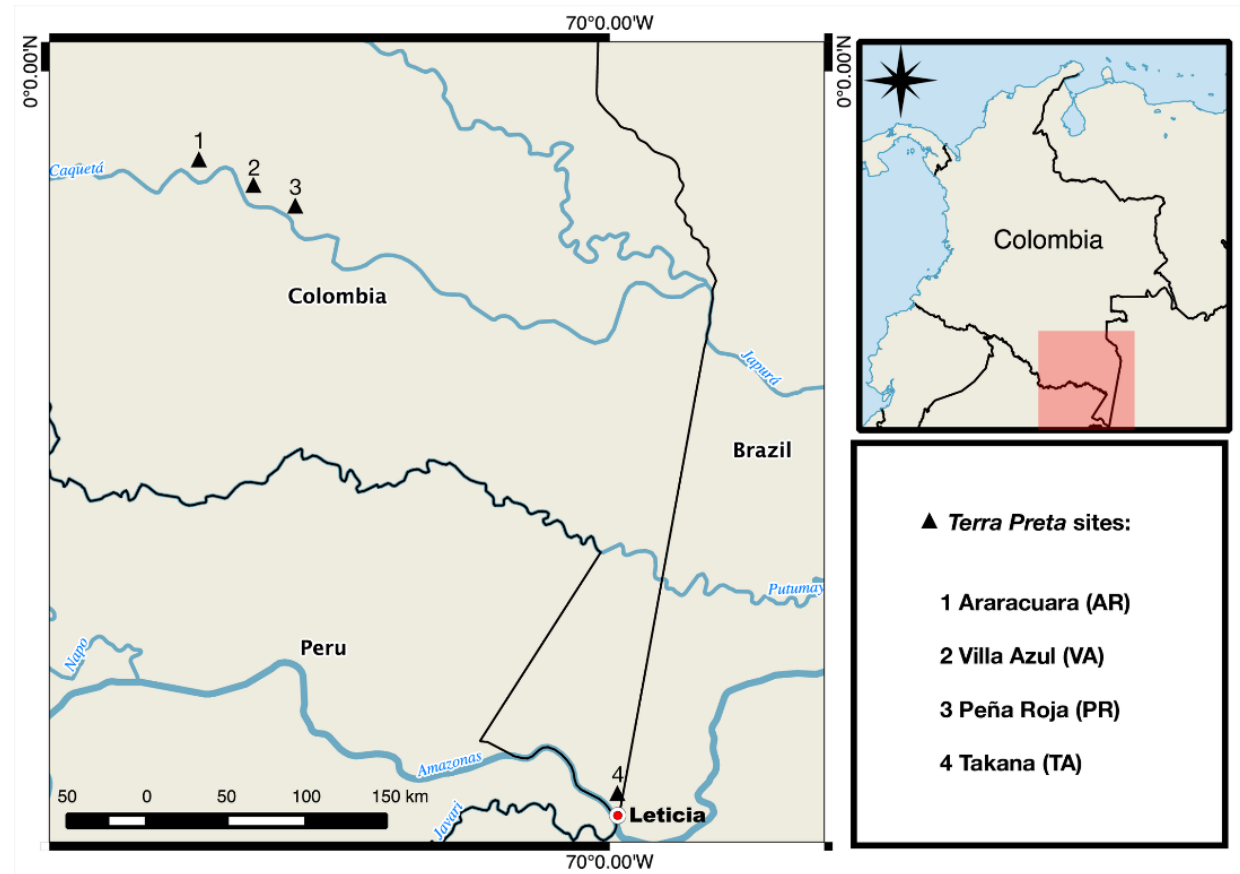

Figure 1. TP sites studied in the Colombian Amazon region. Four TP sites and four surrounding soils were sampled near the Caquetá River and Amazon River in Colombia. Made by the author with QGIS using Natural Earth Data.

\section{Materials and Methods}

\subsection{Sites and Sampling}

Typically, TP sites have been found in "Terra firme", a Portuguese term to denote places not subjected to seasonal flooding $[57,58]$. In recent years, TP sites have also been reported in fertile floodplains of the Brazilian Amazon [30] but so far not in the Colombian part. Hence, all sites sampled for this study were found in Terra firme with negligible slopes and near the rivers' floodplains [27]. The Araracuara, Villa Azul and Peña Roja sites were located close to the Caquetá River (white water, Figure 1; please refer to Table 1 for the coordinates). The texture of Peña Roja was loamy to sandy, while Villa Azul soils presented a sandier texture and Araracuara was a clay soil. The region of the middle Caquetá River is almost completely covered by mature rainforest, pertaining to the life zone of Humid Tropical Forest (bH-T) of the Holdridge life-zone system with a mean temperature of $25.7^{\circ} \mathrm{C}$ and a mean yearly precipitation of about $3060 \mathrm{~mm}$ [59]. Many of the most species-rich families of the region's vegetation are tree families, with shrubs, (emi) epiphytes and climbers present with relatively few species [60]. The TP sampled near Leticia was located close to the "Quebrada Takana", a white-water watershed. The relative humidity in Leticia reaches $81-84 \%$, and the mean annual temperatures oscillate between 25 and $26^{\circ} \mathrm{C}$, with multiannual mean precipitation of $3400 \mathrm{~mm}$ [26]. The TP sites are located close to indigenous settlements; for detailed information about the native communities and their knowledge and use of these soils, please refer to [32]. 
Table 1. Chemical and physical parameters of Terra Preta (TP) and adjacent (ADJ) soils in the Colombian Amazon.

\begin{tabular}{|c|c|c|c|c|c|c|c|c|c|c|}
\hline Coordinates & $\begin{array}{c}\text { Munsell Color/ } \\
\text { Chroma }\end{array}$ & ${\text { Texture }(W R B)^{1}}^{1}$ & Depth (cm) & $\begin{array}{c}\text { Dry Density } \\
\left(\text { ton } \mathrm{m}^{-3}\right)\end{array}$ & $\mathrm{pH}\left(\mathrm{H}_{2} \mathbf{0}\right)$ & SOC $\left(\mathrm{g} \mathrm{kg}^{-1}\right)$ & $\mathrm{N}_{\text {total }}\left(\mathrm{g} \mathrm{kg}^{-1}\right)$ & $P_{\text {total }}\left(\mathrm{mg} \mathrm{kg}^{-1}\right)$ & $\begin{array}{c}\text { SUM BPCA }^{2} \\
{\left[\mathrm{~g} \mathrm{C} \mathrm{Kg}^{-1}\right]}\end{array}$ & B5CA: B6CA \\
\hline \multirow{4}{*}{$\begin{array}{c}\text { TP Araracuara } \\
00^{\circ} 36^{\prime} 36^{\prime} 6^{\prime \prime} \mathrm{S} \\
72^{\circ} 23^{\prime} 26^{\prime} 9^{\prime \prime} \mathrm{W}\end{array}$} & 10YR 3/2 & SL & $0-10$ & 1.04 & $4.7 \pm 0.3$ & 19.1 & 3.0 & 1016.0 & 179.1 & 0.79 \\
\hline & 10YR 4/2 & SL & $10-20$ & 1.06 & $4.67 \pm 0.4$ & 26.8 & 2.1 & 865.2 & 215.7 & 0.79 \\
\hline & 10YR 4/2 & SL & $20-40$ & 1.11 & $4.52 \pm 0.1$ & 30.1 & 2.1 & 934.0 & 309.1 & 0.88 \\
\hline & $10 Y R 5 / 4$ & SCL & $40-60$ & 1.38 & $4.07 \pm 0.2$ & 21.4 & 0.9 & 1269.2 & 80.9 & 0.84 \\
\hline \multirow{4}{*}{$\begin{array}{c}\text { ADJ Araracuara } \\
00^{\circ} 36^{\prime} 27^{\prime \prime} \mathrm{S} \\
72^{\circ} 22^{\prime} 52^{\prime} 2^{\prime \prime} \mathrm{W}\end{array}$} & 7.5YR 5/4 & SCL & $0-10$ & 1.15 & $4.61 \pm 0.3$ & 16.9 & 2.3 & 221.5 & 96.0 & 0.87 \\
\hline & 7.5YR 4/4 & SCL & $10-20$ & 1.16 & $4.42 \pm 0.4$ & 18.1 & 1.5 & 190.4 & 80.0 & 0.82 \\
\hline & 7.5YR $4 / 6$ & SCL & $20-40$ & 1.26 & $4.75 \pm 0.4$ & 17.8 & 0.9 & 172.2 & 51.4 & 0.79 \\
\hline & 7.5YR $6 / 6$ & $\mathrm{CL}$ & $40-60$ & 1.28 & $4.28 \pm 0.3$ & 14.5 & 0.6 & 174.4 & 21.3 & 0.75 \\
\hline \multirow{4}{*}{$\begin{array}{c}\text { TP Villa Azul } \\
00^{\circ} 34^{\prime} 31^{\prime} 5^{\prime \prime} \mathrm{S} \\
072^{\circ} 06^{\prime} 52^{\prime} 4^{\prime \prime} \mathrm{W}\end{array}$} & $2.5 Y 41$ & SL & $0-10$ & 1.62 & $4.95 \pm 0.1$ & 1.8 & 0.11 & 302.0 & 94.2 & 0.88 \\
\hline & $2.5 Y 4 / 2$ & SL & $10-20$ & 1.47 & $4.52 \pm 0.2$ & 1.3 & 0.08 & 118.3 & 78.0 & 0.85 \\
\hline & $2.5 Y 5 / 2$ & SL & $20-40$ & 1.53 & $4.64 \pm 0.2$ & 1.4 & 0.08 & 143.0 & 74.8 & 0.83 \\
\hline & $2.5 Y 7 / 1$ & SL & $40-60$ & 1.47 & $4.67 \pm 0.1$ & 0.8 & 0.04 & 71.4 & 58.7 & 0.85 \\
\hline \multirow{4}{*}{$\begin{array}{c}\text { ADJ Villa Azul } \\
00^{\circ} 34^{\prime} 26.8^{\prime \prime} \mathrm{S} \\
072^{\circ} 06^{\prime} 48.5^{\prime \prime} \mathrm{W}\end{array}$} & $5 Y 4 / 1$ & SL & $0-10$ & 1.25 & $4.41 \pm 02$ & 0.8 & 0.05 & 36.7 & 46.4 & 0.88 \\
\hline & $5 Y 6 / 1$ & SCL & $10-20$ & 1.46 & $4.42 \pm 0.1$ & 0.9 & 0.05 & 35.7 & 55.8 & 0.88 \\
\hline & $5 Y 7 / 1$ & SCL & $20-40$ & 1.46 & $4.33 \pm 0.3$ & 0.7 & 0.04 & 30.9 & 25.5 & 0.82 \\
\hline & $5 Y 8 / 1$ & SCL & $40-60$ & 1.45 & $3.98 \pm 0.4$ & 0.2 & 0.03 & 22.7 & 3.5 & 1.00 \\
\hline \multirow{2}{*}{$\begin{array}{c}\text { TP Peña Roja } \\
00^{\circ} 39^{\prime} 37^{\prime} 4^{\prime \prime} \mathrm{S} \\
72^{\circ} 05^{\prime} 00^{\prime} 00^{\prime \prime} \mathrm{W}\end{array}$} & 10YR 3/1 & LS & $0-10$ & 1.42 & $4.34 \pm 0.1$ & 1.4 & 0.07 & 1329.7 & 91.9 & 0.86 \\
\hline & $10 \mathrm{YR} 4 / 2$ & LS & $10-20$ & 1.41 & $4.11 \pm 0.2$ & 1.3 & 0.06 & 1256.0 & 97.8 & 0.84 \\
\hline \multirow{4}{*}{$\begin{array}{c}\text { ADJ Peña Roja } \\
00^{\circ} 39^{\prime} 25^{\prime \prime} \mathrm{S} \\
72^{\circ} 05^{\prime} 00^{\prime} 6^{\prime \prime} \mathrm{W}\end{array}$} & 10YR 5/4 & LS & $0-10$ & 1.18 & $4.9 \pm 0.2$ & 0.8 & 0.05 & 53.0 & 31.5 & 0.79 \\
\hline & 10YR 6/3 & LS & $10-20$ & 1.27 & $4.59 \pm 0.3$ & 1.0 & 0.07 & 67.1 & 27.5 & 0.74 \\
\hline & $10 \mathrm{YR} 6 / 3$ & SL & $20-40$ & 1.29 & $4.43 \pm 0.1$ & 0.9 & 0.05 & 57.8 & 28.1 & 0.93 \\
\hline & $10 \mathrm{YR} 7 / 8$ & SL & $40-60$ & 1.28 & $4.15 \pm 0.4$ & 0.5 & 0.02 & 54.6 & 14.6 & 0.67 \\
\hline \multirow{4}{*}{$\begin{array}{c}\text { TP Takana } \\
04^{\circ} 07^{\prime} 08^{\prime} 8^{\prime \prime} \mathrm{S} \\
069^{\circ} 55^{\prime} 15^{\prime} 7^{\prime \prime} \mathrm{W}\end{array}$} & 7.5YR 4/4 & SL & $0-10$ & 1.06 & $4.66 \pm 0.2$ & 1.6 & 0.14 & 441.9 & 213.2 & 0.89 \\
\hline & 7.5YR 5/4 & $\mathrm{SL}$ & $10-20$ & 1.10 & $4.68 \pm 0.2$ & 1.5 & 0.11 & 470.1 & 362.0 & 0.92 \\
\hline & 7.5YR 5/6 & SCL & $20-40$ & 1.22 & $4.2 \pm 0.1$ & 0.8 & 0.07 & 514.6 & 148.4 & 0.98 \\
\hline & 7.5YR 7/6 & SCL & $40-60$ & 1.45 & $4.64 \pm 0.4$ & 0.5 & 0.07 & 301.0 & 60.3 & 0.98 \\
\hline \multirow{4}{*}{$\begin{array}{c}\text { ADJ Takana } \\
04^{\circ} 06^{\prime} 59^{\prime} 3^{\prime \prime} \mathrm{S} \\
069^{\circ} 55^{\prime} 16^{\prime} 7^{\prime \prime} \mathrm{W}\end{array}$} & 7.5YR 4/3 & SCL & $0-10$ & 0.94 & $4.24 \pm 0.3$ & 2.3 & 0.22 & 97.6 & 100.3 & 0.70 \\
\hline & 7.5YR 6/6 & SCL & $10-20$ & 1.13 & $4.34 \pm 0.2$ & 1.8 & 0.19 & 82.9 & 82.8 & 0.67 \\
\hline & 7.5YR 7/3 & SCL & $20-40$ & 1.16 & $4.39 \pm 0.1$ & 1.5 & 0.15 & 64.9 & 132.2 & 1.03 \\
\hline & 7.5YR 7/6 & $\mathrm{CL}$ & $40-60$ & 1.20 & $4.14 \pm 0.3$ & 0.5 & 0.10 & 51.2 & 4.7 & 1.10 \\
\hline
\end{tabular}

${ }^{1} \mathrm{SL}=$ Sandy Loam, SCL = Sandy Clay Loam, CL = Clay Loam, LM = Loamy Sand, ${ }^{2}$ BPCA = benzenpolycarboxylic acids, B5CA = pentacarboxylic acid, B6CA = mellitic acid. 
We identified the TP sites by the abundance of ceramic sherds, charcoal particles, and a thick A horizon with darker coloration according to the Munsell color chart compared to the surrounding soils. Studies on ceramic composition have dated the Takana site to be around 1170 cal yr BP [23], and older dates exist for the middle Caquetá region sites [28]. Before sampling, TP sites were identified by talking to the locals, followed by thoroughly auguring the whole TP site and surrounding soils. Due to legal restrictions, we did not open multiple profiles at each site, but consider each TP site with its ADJ soil as one replicate out of the four sites investigated.

The thickness of the A horizon varied from 0 to $5 \mathrm{~cm}$ in most ADJ soils but extended further down to $40 \mathrm{~cm}$ in the TP soils. The A horizons faded into B horizons, which were also different in thickness $(40-60 \mathrm{~cm})$ and showed pockets of distinct grey, brown, and black colors. The B horizons of the TP sites were almost identical in appearance to surrounding Ferralsols and Acrisols, as found in other studies [41].

We sampled the ADJ soils within a radius of $500 \mathrm{~m}$ from the TP sites. The main criteria to identify non-TP areas were:

1. The absence of ceramic sherds;

2. Thickness of the A horizon (not more than $10 \mathrm{~cm}$ );

3. Lighter color of the A horizon as is a standard practice in many TP studies $[7,37,41]$.

The ADJ soils were located in the same topographical position as the TP sites. The texture was similar between the anthropogenic and non-anthropogenic soils, suggesting that both TP and associated reference soils developed from the same parent material $[41,53]$. The soils were sampled at four depths: 0-10 cm, 10-20 cm, 20-40 cm and 40-60 cm. About $500 \mathrm{~g}$ for each depth were collected from each soil group (TP and ADJ) for physicochemical analyses. A total of 32 soil samples were obtained for physicochemical analyses, corresponding to the 4 depths for each soil group (TP and ADJ) collected at the four locations.

\subsection{Analytical Procedures}

Soil samples from each site were air-dried and sieved to $2 \mathrm{~mm}$, homogenized, and finely ground for combustion analyses. Soil $\mathrm{pH}$ was determined in 1:2.5 soil:water suspension using a glass electrode. Soil Organic Carbon (SOC) and total nitrogen (N) were determined after dry combustion using a CNS elemental analyzer (vario MICRO cube; Elementar, Hanau, Germany). Total elemental phosphorus (P), calcium (Ca), magnesium $(\mathrm{Mg})$, potassium $(\mathrm{K})$, sodium $(\mathrm{Na}), \mathrm{Al}$, and iron $(\mathrm{Fe})$ were determined after Aqua regia digestion (mixture of concentrated nitric acid and concentrated hydrochloric acid) and quantified using inductively coupled plasma optical emission spectrometry (ICP-OES; Ultima 2, HORIBA Jobin Yvon, Longjumeau, France).

Phosphorus (P) fractions were determined by a sequential extraction following a modified Hedley extraction procedure [61]. The interpretation of $\mathrm{P}$ in each extract is based on an understanding of the action of individual extractants, their sequence, and their relationship to the chemical and biological properties of the soil [37]. Resin-P is reasonably well defined as freely exchangeable and bioavailable inorganic phosphorus $\left(\mathrm{P}_{\mathrm{i}}\right)$. The bicarbonate-extract presumably removes labile $\mathrm{P}_{\mathrm{i}}$ and organic phosphorus $\left(\mathrm{P}_{\mathrm{o}}\right)$ sorbed on soil minerals and a small amount of microbial $\mathrm{P}$. The sodium hydroxide-extractable $\mathrm{P}$ largely represents Aland Fe-associated $\mathrm{P}_{\mathrm{i}}$ and $\mathrm{P}_{\mathrm{o}}$ that are strongly held to soil surfaces by chemisorption. Using dilute $\mathrm{HCl}$ particularly isolates $\mathrm{Ca}$-bound $\mathrm{P}_{\mathrm{i}}$, and there is rarely any $\mathrm{P}_{\mathrm{o}}$ in this extract. All samples were thus analyzed as follows: A half gram of soil was weighed (in duplicates) into a $50 \mathrm{~mL}$ centrifuge tube, then $30 \mathrm{~mL}$ of deionized water and two strips of anion-exchange resin were added to the tubes. The tubes were shaken for $16 \mathrm{~h}$ on a horizontal shaker. After the resin strips were removed, the tubes were centrifuged for $20 \mathrm{~min}$ at $0{ }^{\circ} \mathrm{C}$ at $2500 \times g$, and supernatant water was discarded. The resin strips were placed in a clean $50 \mathrm{~mL}$ tube with $20 \mathrm{~mL}$ of $0.5 \mathrm{M} \mathrm{HCl}$, and shaken for $16 \mathrm{~h}$. then, $30 \mathrm{~mL}$ of $0.5 \mathrm{M} \mathrm{NaHCO}_{3}$ ( $\mathrm{pH}$ 8.5) were added to each of the tubes containing the soil samples, vortexed, shaken for $16 \mathrm{~h}$, and centrifuged as above. The supernatant was filtered (Quantitative Filter Paper ashless, DP 5892125, Hahnemühle, Dassel, Germany). The extraction process was repeated 
using $30 \mathrm{~mL}$ of $0.1 \mathrm{M} \mathrm{NaOH}$ and $1 \mathrm{M} \mathrm{HCl}$ as above. $\mathrm{P}_{\mathrm{i}}$ concentration in each extract was determined colorimetrically on a spectrophotometer (Specord 205; Analytic Jena, Germany) using the molybdenum blue method [62]. The total amount of $\mathrm{P}$ in each fraction was quantified by inductively coupled plasma-optical emission spectrometry (ICP-OES) with the same specifications as used for the other elements. $P_{O}$ content was then calculated as the difference of total and inorganic $\mathrm{P}$.

Black carbon (BC) was assessed in all samples using benzene polycarboxylic acids (BPCAs) as molecular markers [48] and following the revised protocol of [49,63]. After purification, the BPCAs were silylated and analyzed with a Hewlett Packard 6890 gas chromatograph (Hewlett Packard $\mathrm{GmbH}$, Waldbronn, Germany) equipped with a flame ionization detector and a HP-5 capillary column (30 m, $0.32 \mathrm{~mm}$ i.d., $0.25 \mathrm{~mm}$ film thickness, Macherey-Nagel, Düren, Germany; for oven program see [49]). Deviation from duplicate analysis was $<5 \%$ and recovery of the internal standard (citric acid) was always $>79 \%$. As a measure of the chemical structure and condensation of BC particles, we analyzed the ratio of BPCAs with 5 or 6 carboxyl groups (B5CA:B6CA). To convert BPCA to BC, a conversion factor of 2.27 was used [48]. BC contents of each sample were then normalized to the respective SOC contents.

Amino sugar analysis was prepared according to the protocol of Zhang and Amelung [64]. The method involves hydrolysis with $6 \mathrm{M} \mathrm{HCl}$ for $8 \mathrm{~h}$ at $105^{\circ} \mathrm{C}$. After cooling, the samples were filtrated, concentrated with a rotary evaporator at $1.5 \mathrm{MPa}$ and $40{ }^{\circ} \mathrm{C}$, re-dissolved in millipore water, adjusted to $\mathrm{pH}$ 6.6-6.8, and centrifuged (1500 $\mathrm{g}$ for $10 \mathrm{~min}$ ). The clear supernatant was freeze-dried, washed three times with $1.5 \mathrm{~mL}$ methanol, transferred into reactivials, and then evaporated with a stream of pure nitrogen $(>99.9 \mathrm{n} / \mathrm{n} \%)$. After transformation to aldononitrile derivatives, the amino sugar derivatives were separated by gas chromatography-mass spectrometry (MSD: 5973, Agilent Technologies, Böblingen, Germany) with a column OPTIMA ${ }^{\circledR} 5$ MS (Machery-Nagel, Düren, Germany). Helium was used as a carrier gas with a flow rate set at $1.1 \mathrm{~mL} \mathrm{~min}^{-1}$ at $0.8 \mathrm{bar}$. The split ratio was 30:1. Final detection was then performed using mass spectrometry after electron ionization (EI) and selected ion monitoring (SIM) mode, looking at mass-to-charge ratios $(m / z+)$ of 89,99 , 236, 237, 264, 265 and 356, 357. Myo-inositol was added to the samples after hydrolysis and endosulfane was added to the derivatized reagent to assess the recovery of myo-inositol: it averaged $45.5 \pm 18.3 \%$.

\subsection{Calculations}

Element stocks were calculated as the mass of the element:

$$
\mathrm{M}_{\text {element }}=\text { conc } \times \rho_{\mathrm{b}} \times \mathrm{T} \times 10,000 \mathrm{~m}^{2} \mathrm{ha}^{-1}
$$

where $\mathrm{M}_{\text {element }}$ is the element mass per unit area $\left(\mathrm{kg} \mathrm{ha}^{-1}\right)$, conc is the element concentration $\left(\mathrm{kg}\right.$ ton $\left.^{-1}\right), \rho_{\mathrm{b}}$ is bulk density (ton $\mathrm{m}^{-3}$ ) and $\mathrm{T}$ is the thickness of the respective soil layer $(\mathrm{m})$. The conversion factor of $10,000 \mathrm{~m}^{2} \mathrm{ha}^{-1}$ is used to scale stocks to the hectare.

All data were analyzed using Stata/SE 14.2 for Mac (64-bit Intel). After testing for normal distribution using the Shapiro-Wilk test, we assessed the statistical reliability of the relationship between different soil samples with multiple regressions using the soil types (TP or ADJ), site locations in Colombia (Araracuara, Villa Azul, Peña Roja, Takana) and the different depths to predict specific changes on physicochemical soil parameters. All data of the regression model were tested for normality and homoscedasticity of residuals. Influential values were predicted and cut off using Cook's D overall measure of influence. The same procedure as for the soil parameters was carried out for the linear regressions to assess the reliability of the effect of the type of soil, location and depth on the different element stocks. The marginal predictions of generalized mixed-effects linear model (GLM) were used to plot significant differences and assess the confidence intervals (CI). Specifically, we used mixed-effects GLM's (GLMM) to test the effect of the type of soil (TP or ADJ, fixed effect) and the site's locations (4 sites, random effect) and the depths (4 depths, random effect). In the structure of the GLM, the depths were nested within each site and each site 
nested within soil group (TP or ADJ). Consequently, the paired sampling of TP and ADJ soils at each site was considered in the model. When the data of a specific physicochemical parameter did not fulfill the normality assumption, a two-sample Wilcoxon rank-sum (Mann-Whitney) test was used to assess the reliability of the effect of the type of soil (TP or ADJ) on the GLM. To assess the reliability of the model comparing the effect of the location and depth, a Kruskal-Wallis (equality of populations) rank test was used when normality of the residuals was not given.

\section{Results}

\subsection{Basic Chemical and Physical Soil Parameters}

The Munsell color evaluation confirmed the darker coloration of TP compared to ADJ soils (Table 1). The darker colors at a depth between $20 \mathrm{~cm}$ to $40 \mathrm{~cm}$ generally coincided with the presence of ceramics, although some potsherds were also found on the surface of the topsoil (Figure S1, Supplementary Material). Both TP and ADJ soils had a low pH value with no significant differences between the two types $(z=-1.716, p=0.086)$, although taking a threshold of $\mathrm{pH} 4.5$ for Al toxicity, the ADJ soils were below, while TP soil samples tended to be slightly above, the threshold $(\mathrm{pH}=4.52)$.

Concentrations of SOC and total P were all significantly $(p<0.0001)$ higher in the TP profiles than in the ADJ soils. GLM data on the effect of location and depth revealed significant differences between TP and ADJ soil samples ( $\left.\mathrm{df}=1 ; \mathrm{X}^{2}=11.13 ; p<0.0009\right)$, between the different sites $\left(\mathrm{df}=3 ; \mathrm{X}^{2}=56.24 ; p<0.0001\right)$ and with depth $(\mathrm{df}=3$; $\left.\mathrm{X}^{2}=111.76 ; p<0.0001\right)$. Total $\mathrm{P}$ concentration decreased according to locations in the order Peña Roja $>$ Araracuara $>$ Takana $>$ Villa Azul, with total P concentration ranging from $1289 \mathrm{mg} \mathrm{kg}^{-1}$ in the Peña Roja TP soil profile to $31.8 \mathrm{mg} \mathrm{kg}^{-1}$ in the Villa Azul adjacent soil profile. Differences in total P concentration between TP and ADJ soils significantly decreased in the order Araracuara > Takana > Peña Roja > Villa Azul.

No significant differences between the TP soil $\mathrm{N}$ concentrations and those of the surrounding soils $(z=-0.358 ; p=0.72)$ were found. Yet, GLM results suggested significant $\mathrm{N}$ concentration differences between sites $\left(\mathrm{df}=3 ; \mathrm{X}^{2}=158.47 ; p<0.0001\right)$ and significant reduction with depth $\left(\mathrm{df}=3 ; \mathrm{X}^{2}=95.85 ; p<0.0001\right)$. As residuals were non-normally distributed, an additional Kruskal-Wallis test confirmed inter-site differences ( $\mathrm{df}=3$; $\left.\mathrm{X}^{2}=13.97 ; p=0.0029\right)$ and a correlation of depth with lower $\mathrm{N}$ concentration $(\mathrm{df}=3$; $\left.\mathrm{X}^{2}=10.94 ; p=0.012\right)$.

\subsection{Element and Black Carbon Stocks}

A linear model that considered the effect of the interaction between the type of soil and the location and depth of the soil samples best fitted all element stock values $\left(p<0.0001 ; \mathrm{R}^{2}=0.83-0.93\right)$. Total SOC stocks in 0 to $60 \mathrm{~cm}$ depth in the TP soil profiles differed significantly from those in the ADJ soils (Figure $3 a)\left(d f=1 ; X^{2}=20.03 ; p<0.0001\right)$. Significant differences were recorded between BC concentrations of TP and ADJ soil profiles $(p<0.0001)$ as well as between different depths $(p<0.05)$, thus supporting the visual differences in BC concentrations for the various soil profiles (Figure 2). 
(a)

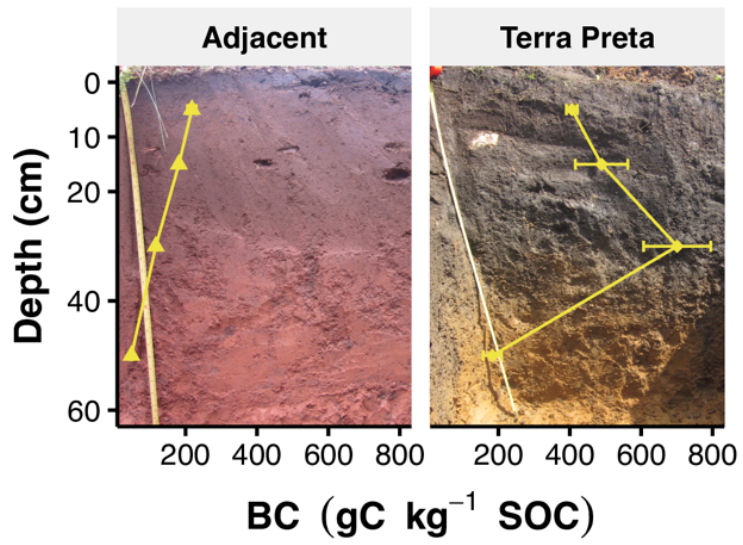

(c)

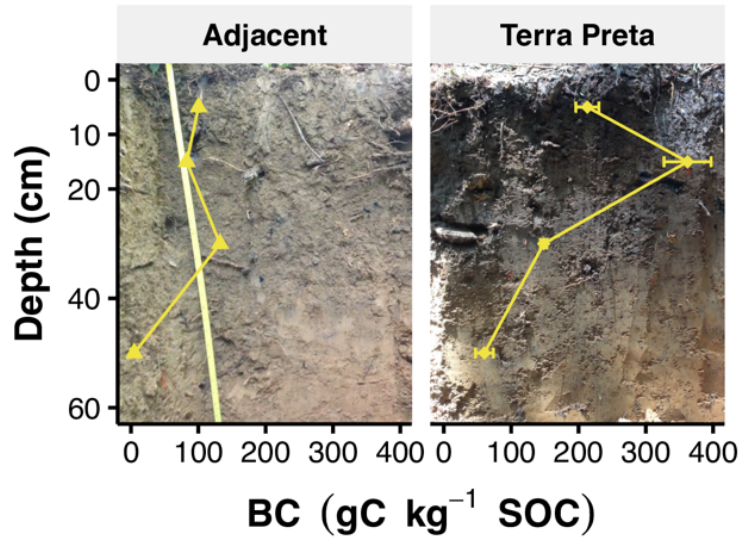

(b) Peña Roja

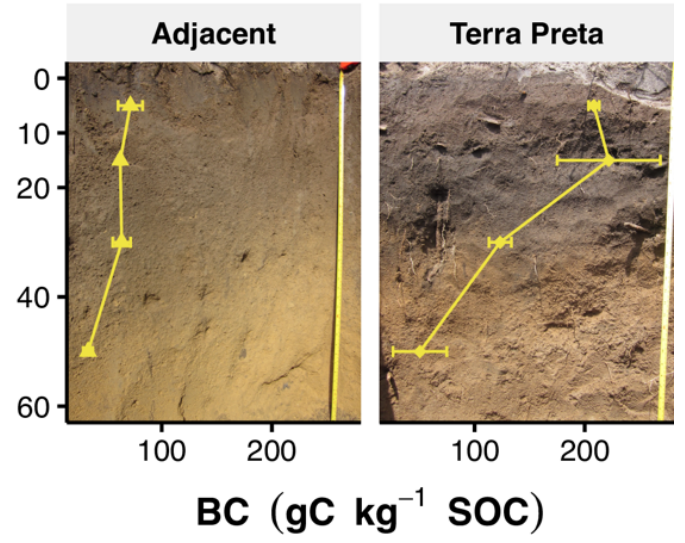

(d)

\section{Villa Azul}

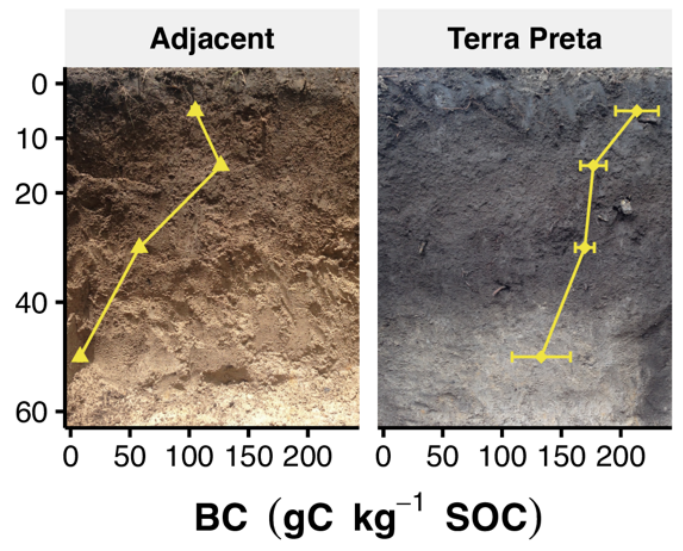

Soil Adjacent $\quad$ Terra Preta

Figure 2. Soil morphology and black carbon (BC) contents in Terra Preta and adjacent (ADJ) soils at the four study sites ((a-d); see Table 1 for details on soil properties). Due to incorporation of the images into the graph, appearance of colors in the photo may differ from Munsell colors recorded in the field.

There was, however, no consistent difference in B5CA:B6CA ratios among TP and ADJ soil sites. As a mean across all sites, differences between the soils were significant $(\mathrm{z}=-3.08$; $p=0.002)$, with about three times larger BC stocks in TP profiles (5021.2 $\pm 610.7 \mathrm{~kg} \mathrm{ha}^{-1}$ for the $95 \%$ confidence interval) than in the ADJ soils, as a mean of the model predictions $\left(1690.11 \pm 590.6 \mathrm{~kg} \mathrm{ha}^{-1}\right)$ (Figure 3b).

The P stocks in the two different soil types showed the most considerable and significant differences $(\mathrm{z}=-4.28 ; p<0.0001)$ between all investigated parameters, with mean $\mathrm{P}$ stocks around seven times larger in TP profiles $\left(1103.43 \pm 93.73 \mathrm{~kg} \mathrm{ha}^{-1}\right)$ than in ADJ soils $\left(150.69 \pm 87.4 \mathrm{~kg} \mathrm{ha}^{-1}\right)$, and this difference was highly significant (Figure 3c). 
(a)

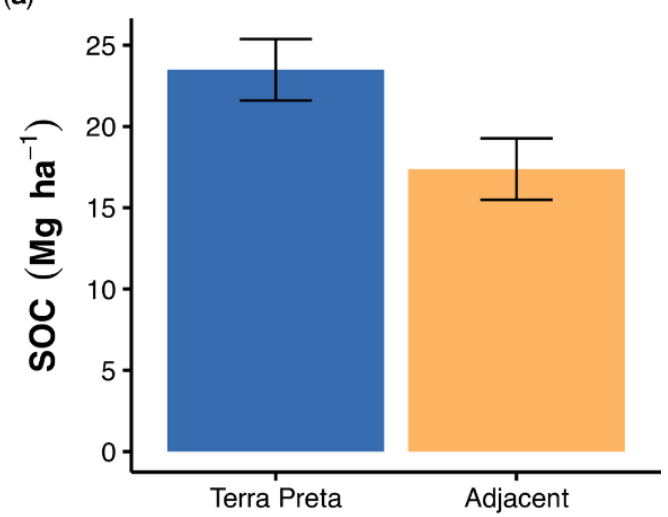

(b)

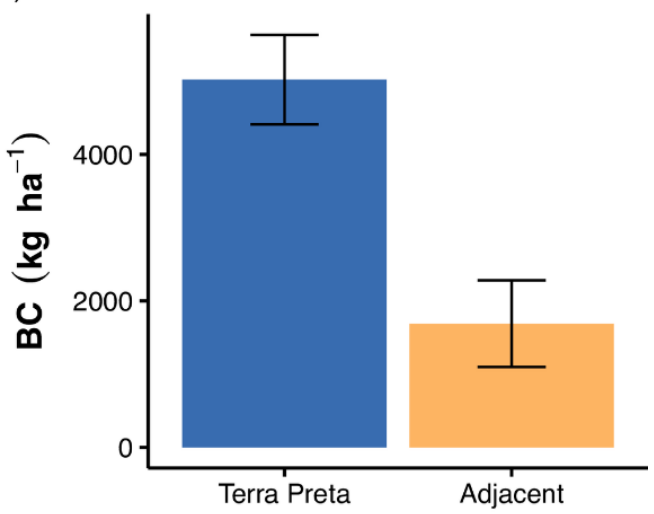

(c)

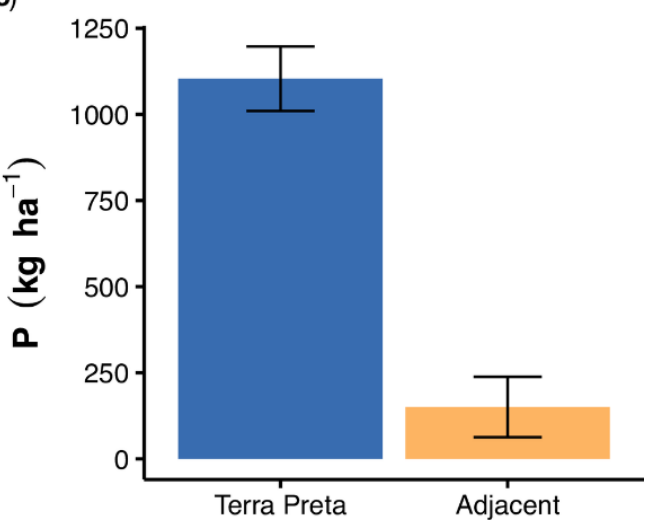

Figure 3. Mean stock predictions of (a) soil organic carbon (SOC), (b) black carbon (BC), and (c) phosphorus (P) in the Terra Preta (TP) and adjacent (ADJ) soils under study.

\subsection{P Fractions}

Only fractions of the total nutrient contents are available to plants; therefore, we performed a sequential $P$ fractionation [61]. The interaction between the type, location, and the depth of the soils sampled explained $86 \%$ of the variance observed in P fraction contents. Elevated amounts of total P in TP soils thus corresponded to higher P concentrations in each of the fractions, though to a different degree. Plant-available forms of Free Exchangeable $P_{i}$ $\left(\right.$ FE- $\left.P_{i}\right)$ and Adsorbed $P_{i}\left(\right.$ Ad- $\left.P_{i}\right)$ were significantly higher by a factor of 15 in TP compared with ADJ soils (FE- $\mathrm{P}_{\mathrm{i}}: \mathrm{z}=-4.25, p<0.0001$; Ad- $\left.\mathrm{P}_{\mathrm{i}}: \mathrm{z}=-3.78, p<0.0002\right)$. Organic $\mathrm{P}$ (bicarbonate- $\mathrm{P}_{\mathrm{O}}+$ hydroxide- $\mathrm{P}_{\mathrm{o}}$ ) contents were elevated by a factor of seven in relation to the ADJ soils $(\mathrm{z}=-4.23, p<0.0001)$. TP soils also showed a shift of $\mathrm{P}$ proportions linked to a greater fraction of stable P pools, such as $\mathrm{P}$ extractable with diluted $\mathrm{HCl}(\mathrm{Ca}-\mathrm{P})$ and concentrated acid, and acid-digested P (Occluded P). High inter-site differences (as 
indicated by error bars in Figure 4) and very little P content were detected in ADJ soils (Figure 4).

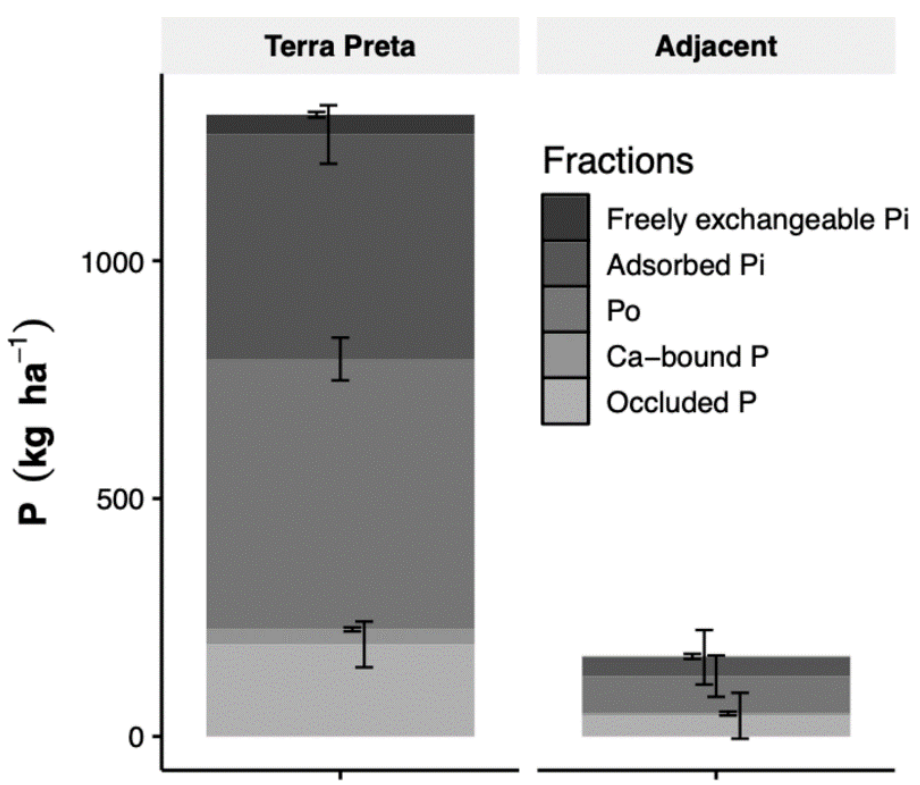

Figure 4. Phosphorus fractions in Terra Preta (TP) and adjacent (ADJ) soils. Freely exchangeable inorganic $\mathrm{P}(\mathrm{Pi})=$ resin-Pi, adsorbed $\mathrm{Pi}=$ bicarbonate (0.5 M NaHCO3)-Pi thydroxide $(0.1 \mathrm{M} \mathrm{NaOH})$ $\mathrm{Pi}$, organic $\mathrm{P}(\mathrm{Po})=$ bicarbonate $\mathrm{Po}+$ hydroxide-Po, calcium-bound $\mathrm{P}=$ dilute acid $(1 \mathrm{M} \mathrm{HCl})-\mathrm{P}$, and occluded $\mathrm{P}=$ concentrated-acid $(97 \% \mathrm{HCl})$ and acid-digested $(1: 3 v / v$ concentrated HNO3: concentrated $\mathrm{HCl}$ mixture) $\mathrm{P}$ for the TP and ADJ soils. The error bars represent the $95 \%$ confidence intervals for P stocks of adjacent and TP soils across all four sites.

\subsection{Amino Sugars}

The mean recovery of the first internal standard (myo-inositol) analyses was only $50 \%$ and thus below that commonly found for other samples when performing these analyses in our lab (the typical recovery usually exceeds $70 \%$, see, e.g., $[64,65])$. Hence, the high content of oxides apparently led to higher losses of the internal standard and, thus, likely also of amino sugars during analyses. Similar problems had also occurred earlier (unpublished data from MSc thesis) for Brazilian TP soils [66]. As with a low recovery of 50\% we do not feel confident to exclude that amino sugar losses were compound-specific, we thus refrain from evaluating amino sugar patterns. The concentrations of amino sugars, however, were not related to analytical recovery and could thus serve at least as an indicator of necromass accrual. Also, the magnitude of amino sugar contents was in similar magnitude (0.19-7.83\% of amino sugar N contribution to TN) as formerly reported by Glaser (1999) and reported in [67], who identified $30 \%$ of $\mathrm{TN}$ in TP soils, of which $4-7 \%$ was amino sugar $\mathrm{N}$. Intriguingly, but similar to total $\mathrm{N}$, amino sugar $\mathrm{N}$ contents were not significantly different among TP and ADJ soils (Figure S2, Supplementary Materials; $\mathrm{z}=1.13 ; p=0.26$ ).

\section{Discussion}

\subsection{Morphological Variation and $p H$ Values in TP Profiles}

The differences in colors observed between the four Colombian TP and ADJ soil profiles confirm both earlier reports in the TP literature $[20,68]$ and a basic variability among TP sites. The topsoil's dark colors are no guarantee for the identification of TP [13]; however, the presence of potsherds in the TP soil matrix points to their anthropogenic origin. Nevertheless, categorizing TP from its color nuances is difficult because TP indicates the epicenter of long-term waste discard areas that fades away into lighter colorations, as found in Terras Mulatas towards the edge of the discard areas [16]. The whole area is then surrounded by the ADJ soils. At the ADJ site at Aracuara, the colors were darker and SOC 
contents were higher than in other ADJ soils (Table 1), suggesting that the Aracuara ADJ soil could have been part of the settlement though not of the main discard area (considering the absence of artifacts), but more research is needed to categorize them as Amazonian Brown Earths (ABE or Terra Mulata). Hence, the qualitative characteristics of Munsell scales make it difficult to translate color schemes into physicochemical soil properties, which we measured.

We recognize the limitations of our data such as the limited number of sampling sites. However, as the four sites were separated by several kilometers distance, we assume that these sites represent independent replications and depth was included as a random effect in the mixed effects modeling [69]. However, the enrichment of specific soil properties in TP samples was a clear pattern in our data and results. The increase of specific soil properties in TP has also been reported in other studies related to specific human activities. For example, Schmidt and colleagues [31] show that the original soil underwent particular modifications according to various activity areas (Table S1).

Our results suggested that there seems to be a strong effect from the parent material represented by the TP sites' location. This effect can also be observed in [31], where the soils from adjacent forest areas show much higher concentrations of OC $\left(35 \mathrm{~g} \mathrm{~kg}^{-1}\right)$ and $\mathrm{P}$ (1077 $\mathrm{mg} \mathrm{kg}^{-1}$ ) compared to the adjacent soils sampled in Colombia, which presented much lower average TOC $\left(11 \mathrm{~g} \mathrm{~kg}^{-1}\right)$ and $\mathrm{P}\left(88 \mathrm{mg} \mathrm{kg}^{-1}\right)$ concentrations. Therefore, a portion of the high nutrient concentrations in the Schmidt et al. study [31] might have its source in the richness of surrounding soils compared to the parent materials where TP soils in Colombia formed. TOC and P concentrations similar to those of Colombian TP sites can be found in the Cipoal do Araticum site in the lower Trombetas River, Brazil (see [31]).

Some of the highest concentrations of $\mathrm{P}$ in Colombian TP, for example, were identified in the $20-40 \mathrm{~cm}$ depth interval. The interval differences, between our methodology (10-20 cm intervals) compared to the 5-10 cm intervals, might be causing a dilution effect. Unfortunately, Schmidt and colleagues [31] did not calculate nutrient stocks to exclude dilution as a plausible cause of the differences. Stocks are very useful in agronomy but frequently not calculated in archaeological surveys due to the great variability in the size of TP sites that can range from less than a hectare up to several square kilometers [44].

Frequently, TP soils have a $\mathrm{pH}$ value in the range of 5.2 to 6.4, suggesting lower levels of exchangeable $\mathrm{Al}$ and higher productivity of crops [70]. Yet, there are also cases of TP sites with moderate [20] and even strong acidity down to $\mathrm{pH} 4.2$ [26], or with unaltered $\mathrm{pH}$ value [16]. Our TP profiles are such examples of strong acidity at most depths (Table 1). As $\mathrm{pH}$ values range around the critical Al toxicity threshold $(\mathrm{pH}=4.5)$, it is questionable whether our four TP sites in the Colombian Amazon were intentionally created for agricultural purposes.

\subsection{Organic Matter, Black Carbon and Phosphorus Stocks in TP Profiles}

Despite the similar $\mathrm{pH}$ values to ADJ soils in all soil profiles, we found that SOC and nutrient contents were significantly enriched in the TP soils, corroborating earlier findings from elsewhere in the Amazon basin [20,46,70,71]. As our statistical analyses clearly demonstrated, discrimination among different TP profiles primarily relied on the contents of total P, SOC, and BC, as also reported for other parts of the region [16]. Yet, the average increase in SOC content was less than 30\%, thus questioning-at least for Colombiaclaims by Glaser and Birk [44] that three-times-higher SOM levels are commonly found in TP relative to surrounding soils, though incidentally we found such differences in BC stocks (Figure 3). Clearly, enrichment of BC appears to be a more sensitive indicator for identifying TP soils than bulk SOC [46].

In three of four cases, the BC contents in the TP profiles peaked at lower depth, thus pointing likely to maxima of past waste enrichments. Yet, even for these BC maxima, the contents varied up to a factor of three within the different TP soils. Across different profile depths, variations were partly even higher (Figure 2), without clear differentiation in BC quality. Differences in the size of ancient local populations may have led to the different 
degrees of waste discards, meaning that each TP profile possibly constitutes a unique fingerprint of ancient local settlement rather than contributing to globally valid properties of these Anthrosols.

Waste discard frequently goes along with an enrichment of $P$ forms. Yet, only few studies addressed $P$ fractions in TP soils, and to the best of our knowledge, so far no research has focused on P forms of TP soils outside of the Brazilian Amazon. Sato et al. [37] found pronounced enrichment of CaP forms (2141 mg kg-1 and $\left.6994 \mathrm{mg} \mathrm{kg}^{-1}\right)$ in two of their four studied Anthrosols, while other TP soils showed very low calcium-bound P concentrations (21 $\mathrm{mg} \mathrm{kg}^{-1}$ and $2 \mathrm{mg} \mathrm{kg}^{-1}$ ). However, easily extractable $\mathrm{P}$ forms (bicarbonate and Nahydroxide-extractable P) were always higher than in ADJ soils (see [37]; p. 199), which was also the case in our TP samples from the Colombian Amazon. Colombian TP soils also confirmed the enrichment of Ca-bound P stocks (Figure 4), which, for Brazilian TP sites, had been assumed to be of biogenic origin $[34,35,68]$. Other $P$ fractions dominating our TP soils correspond to rather stable P pools, such as occluded P (Figure 4). This does not necessarily mean that $\mathrm{P}$ had been added as such, but rather that, due to ongoing $\mathrm{P}$ transformations in these fertile soils, stable P was formed (Figure 4; [37]).

Formation of stable $\mathrm{P}$ forms may involve abiotic aging, like slow diffusion of inorganic $P$ into the interior of oxidic aggregates [72] as well as slow transformations of organically bound $\mathrm{P}$ [73], which altogether may result in changes of $\mathrm{P}$ distribution among soil colloids [74]. The latter process correlated with changes in $\mathrm{pH}$ values, which we did not observe in our study. Transformations of SOM, in turn, usually go along with changes in amino sugar concentrations as markers for microbial residues, which were not significantly enriched in the TP soils. Hence, it seems reasonable to assume that the formation of stable P forms in TP sites likely involved to a considerable extent abiotic process, such as occlusion of oxidic structures by aggregate reformation and (solid-state) diffusion processes [75].

Studies on the long-term persistence of SOM in TP suggest that interaction of $\mathrm{P}, \mathrm{BC}$ and Ca might play a more important role than $\mathrm{BC}$ alone in the protection of SOM [76]. Indeed, studies on the recalcitrance of SOM suggest that association of organic matter with soil minerals is likely to be the predominant mechanism of SOM stabilization [77], resulting in a confounding effect between the high concentrations of $\mathrm{P}$ and Ca usually observed in $\mathrm{TP}$ and the still-debated chemical recalcitrance of $\mathrm{BC}$ alone.

\section{Conclusions}

Terra Preta soils with unique SOC, BC, and $\mathrm{P}$ enrichment were found in two regions of Colombia. However, the degree of element enrichment varied across the sites, both in TP and in the surrounding soils. Hence, no generalization on TP soil properties can be made for the studied TP sites in the Colombian Amazon. Instead, it seems that higher accrual of $\mathrm{P}$ and $\mathrm{BC}$ in TP soils also correlates with high $\mathrm{P}$ and $\mathrm{BC}$ contents in the surrounding soils, declining in the order Araracuara > Takana > Villa Azul (Peña Roja being an exception), indicating that larger pre-Columbian populations particularly settled in areas with better soils. Still, even if populations were settling near or around better soils, to better understand the dynamics of TP formation, studies on waste decay and formation of middens should be implemented.

Supplementary Materials: The following are available online at https: / www.mdpi.com/article / 10.3390/su13137088/s1, Figure S1: Potsherds found in one of the sites (PR), Figure S2: Change in amino sugar concentrations with depth, Table S1: Comparison of average TP soil analyses results between activity areas in the Upper Xingu (Central Amazonia) (Modified from [31]).

Author Contributions: Conceptualization, W.A., E.L. and J.M.O.-O.; methodology, J.M.O.-O., S.L.B. and R.M.; validation, S.L.B., W.A., C.P.P.-V. and J.M.O.-O.; formal analysis, J.M.O.-O., W.A., S.L.B. and R.M.; resources, W.A. and C.P.P.-V.; data curation, J.M.O.-O., R.M., S.L.B. and W.A.; writing-original draft preparation, J.M.O.-O.; supervision, W.A., E.L., C.B. All authors have read, edited and agreed to the published version of the manuscript. 
Funding: This research was funded with a scholarship for J.M.O.-O. from the Colombian Department of Science, Technology and Innovation (Convocatoria 679 becas en el exterior de Colciencias).

Institutional Review Board Statement: Not applicable.

Informed Consent Statement: Not applicable.

Data Availability Statement: All data is available in the main text or in the supplementary material.

Acknowledgments: This research was possible by the joint work within the cooperation agreement between the department of soil sciences of the University of Bonn, the Center for Development Research (ZEF for its acronym in German) and the Amazonian Institute for Scientific Research SINCHI in Leticia, Colombia). We thank the $11 \mathrm{~km}$ community in Leticia, especially Roberto Hernandez, and the communities in the middle Caquetá River (Peña Roja, Araracuara and Villa Azul), particularly Hernan, Marino and Jose Moreno for all their support during the fieldwork. J.M.O.-O. thanks Anja Buntschu, Karen Hartmann, Omar and Daniel for their invaluable assistance during soil sampling.

Conflicts of Interest: The authors declare no conflict of interest. The funders had no role in the design of the study; in the collection, analyses, or interpretation of data; in the writing of the manuscript, or in the decision to publish the results.

\section{References}

1. Clement, C.R.; Denevan, W.M.; Heckenberger, M.J.; Junqueira, A.B.; Neves, E.G.; Teixeira, W.G.; Woods, W.I. The domestication of Amazonia before European conquest. Proc. R. Soc. B 2015, 282. [CrossRef]

2. Watling, J.; Iriarte, J.; Mayle, F.E.; Schaan, D.P.; Pessenda, L.C.R.; Loader, N.J.; Street-Perrott, F.A.; Dickau, R.E.; Damasceno, A.; Ranzi, A. Impact of pre-Columbian "geoglyph" builders on Amazonian forests. Proc. Natl. Acad. Sci. USA 2017, 114, 1-6. [CrossRef] [PubMed]

3. de Souza, J.G.; Schaan, D.P.; Robinson, M.; Barbosa, A.D.; Aragão, L.E.O.C.; Marimon, B.H., Jr.; Marimon, B.S.; da Silva, I.B.; Khan, S.S.; Nakahara, F.R.; et al. Pre-Columbian earth-builders settled along the entire southern rim of the Amazon. Nat. Commun. 2018, 9, 1125. [CrossRef] [PubMed]

4. Glaser, B. Prehistorically modified soils of central Amazonia: A model for sustainable agriculture in the twenty-first century. Philos. Trans. R. Soc. B 2007, 362, 187-196. [CrossRef] [PubMed]

5. Schmidt, M. Amazonian Dark Earths: Pathways to sustainable development in tropical rainforests? Bol. Mus. Para. Emílio Goeldi Ciências Hum. 2013, 8, 11-38. [CrossRef]

6. Smith, N.J.H. Anthrosols and human carrying capacity in Amazonia. Ann. Assoc. Am. Geogr. 1980, 70, 553-566. [CrossRef]

7. Schmidt, M.; Heckenberger, M.J. Amerindian anthrosols: Amazonian dark earth formation in the Upper Xingu. In Amazonian Dark Earths: Wim Sombroeks's Vision; Woods, W.I., Teixeira, W.G., Lehmann, J., Steiner, C., WinklerPrins, A.M.G.A., Rebellato, L., Eds.; Springer Science \& Business Media: Dordrecht, The Netherlands, 2008; pp. 163-192.

8. Myers, T.P.; Denevan, W.M.; WinklerPrins, A.M.G.A.; Porro, A. Historical perspectives on Amazonian Dark Earths. In Amazonian Dark Earths; Lehmann, J., Kern, D.C., Glaser, B., Woods, W.I., Eds.; Springer: Dordrecht, The Netherlands, 2003 ; pp. 15-28.

9. Neves, E.; Petersen, J.B.; Bartone, R.N.; da Silva, C.A. Historical and socio-cultural origins of Amazonian Dark Earths. In Amazonian Dark Earths: Origin, Properties, Management; Lehmann, J., Kern, D.C., Glaser, B., Woods, W., Eds.; Kluwer Academic Publishers: Dordrecht, The Netherlands, 2003; pp. 29-50.

10. Rebellato, L.; Woods, W.I.; Neves, E.G. Pre-columbian settlement dynamics in the central Amazon. In Amazonian Dark Earths: Explorations in Space and Time; Glaser, B., Woods, W.I., Eds.; Springer: Dordrecht, The Netherlands, 2004.

11. Neves, E.; Petersen, J. Political economy and pre-columbian landscape transformation in central Amazonia. In Time and Complexity in Historical Ecology: Studies in the Neotropical Lowlands; Balee, W., Erickson, C., Eds.; Columbia University Press: New York, NY, USA, 2006.

12. Love, E. Nature and Culture in Prehistoric Amazonia: Using G.I.S. to Reconstruct Ancient Ethnogenetic Processes from Archaeology, Linguistics, Geography, and Ethnohistory; Lund University: Lund, Sweden, 2011.

13. Kämpf, N.; Woods, W.; Kern, D.C.; Cunha, T.J.F. Classification of Amazonian Dark Earths and other ancient anthopic soils. In Amazonian Dark Earths: Origin, Properties, Management; Lehmann, J., Kern, D.C., Glaser, B., Woods, W., Eds.; Kluwer Academic Publishers: Dordrecht, The Netherlands, 2003; pp. 77-104.

14. Schmidt, M. Historical Landscapes in the Neotropics: A model for prehistoric anthrosol (terra preta) fromation in the Upper Xingu. In Archaeologia Amazonica II; Museu Paraense Emilio Goeldi: Belém, Brazil, 2010; pp. 341-366.

15. Kern, D.; Lima, H.; da Costa, J.; de Lima, H.; Ribeiro, A.; Moraes, B.; Kämpf, N. Terras pretas: Approaches to formation processes in a new paradigm. Geoarchaeology 2017, 32, 694-706. [CrossRef]

16. Fraser, J.; Teixeira, W.; Falcao, N.; Woods, W.; Lehmann, J.; Junqueira, A.B. Anthropogenic soils in the Central Amazon: From categories to a continuum. Area 2011, 43, 264-273. [CrossRef] 
17. Lehmann, J.; Kern, D.C.; Glaser, B.; Woods, W. Amazonian Dark Earths: Origin, Properties and Management; Kluwer Academic Publishers: Dordrecht, The Netherlands, 2003.

18. Sohi, S.P.; Krull, E.; Lopez-Capel, E.; Bol, R. A review of biochar and its use and function in soil. Adv. Agron. 2010, 105, 47-82. [CrossRef]

19. Kögel-Knabner, I.; Amelung, W. Soil organic matter in major pedogenic soil groups. Geoderma 2020, 384, 114785. [CrossRef]

20. Macedo, R.S.; Teixeira, W.G.; Corrêa, M.M.; Martins, G.C.; Vidal-Torrado, P. Pedogenetic processes in anthrosols with pretic horizon (Amazonian Dark Earth) in Central Amazon, Brazil. PLoS ONE 2017, 12. [CrossRef] [PubMed]

21. Eden, M.J.; Bray, W.; Herrera, L.; Mcewan, C. Terra-Preta Soils and Their Archaeological Context in the Caqueta Basin of Southeast Colombia. Am. Antiq. 1984, 49, 125-140. [CrossRef]

22. Herrera, L.; Cavelier, I.; Rodriguez, C.; Mora, S. The technical transformation of an agricultural system in the colombian Amazon. World Archaeol. 1992, 24, 98-113. [CrossRef]

23. Costa, M.; Morcote, G.; Carvalho, M.; Jholy, G.; Molano-Valdes, U. Mineralogy and chemistry of archaeological ceramic fragments from Archaeological Dark Earth Site in Colombian Amazon. Geosciences 2011, 64, 17-23. [CrossRef]

24. Peña-Venegas, C.P.; Kuyper, T.W.; Davison, J.; Jairus, T.; Vasar, M.; Stomph, T.J.; Struik, P.C.; Öpik, M. Distinct arbuscular mycorrhizal fungal communities associate with different manioc landraces and Amazonian soils. Mycorrhiza 2019, 29, 263-275. [CrossRef] [PubMed]

25. Etter, A.; McAlpine, C.; Wilson, K.; Phinn, S.; Possingham, H.P. Regional patterns of agricultural land use and deforestation in Colombia. Agr. Ecosyst. Environ. 2006, 114, 369-386. [CrossRef]

26. Morcote-Rios, G.H.; Sicard, T.L. Las Terras Pretas del Igarapé Takana. Un Sistema de Cultivo Precolombino en Leticia-Amazonas, Colombia; Universidad Nacional de Colombia: Bogotá, Colombia, 2012.

27. Peña-Venegas, C.P.; Verschoor, G.; Stomph, T.J.; Struik, P.C. Challenging current knowledge on Amazonian Dark Earths: Indigenous manioc cultivation on different soils of the Colombian Amazon. Cult. Agric. Food Environ. 2017, 39, 127-137. [CrossRef]

28. Morcote-Rios, G.H. Terras Pretas de Índio of the Caquetá-Japurá River (Colombian Amazonia). Tipití J. Soc. Anthropol. Lowl. South Am. 2013, 11, 30-39.

29. Moraes, C.d.P. O determinismo agrícola na arqueologia amazônica. Estud. Avançados 2015, 29, 25-43. [CrossRef]

30. Macedo, R.; Teixeira, W.G.; Lima, H.N.; Souza, C.; Silva, F.; Encinas, O.C.; Neves, E.G. Amazonian dark earths in the fertile floodplains of the Amazon River, Brazil: An example of non-intentional formation of anthropic soils in the Central Amazon region. Bol. Mus. Para. Emílio Goeldi 2019, 14, 207-227. [CrossRef]

31. Schmidt, M.J.; Py-Daniel, A.R.; Moraes, C.D.; Valle, R.B.M.; Caromano, C.F.; Texeira, W.G.; Barbosa, C.A.; Fonseca, J.A.; Magalhaes, M.P.; Santos, D.S.D.; et al. Dark earths and the human built landscape in Amazonia: A widespread pattern of anthrosol formation. J. Archaeol. Sci. 2014, 42, 152-165. [CrossRef]

32. Peña-Venegas, C.P.; Stomph, T.J.; Verschoor, G.; Echeverri, J.A.; Struik, P.C. Classification and use of natural and anthropogenic soils by indigenous communities of the upper Amazon Region of Colombia. Hum. Ecol. 2016, 44, 1-15. [CrossRef]

33. Lehmann, J.; Campos, C.V.; Vasconselos de Macêdo, J.L.; German, L. Sequential P fractionation of relict anthropogenic dark Earths of Amazonia. In Amazonian Dark Earths: Explorations in Space and Time; Glaser, B., Woods, W.I., Eds.; Springer: Berlin/Heidelberg, Germany, 2004; pp. 113-123.

34. Souza, K.W.d.; Lima, H.N.; Schaefer, C.E.G.R.; Teixeira, W.G.; Pulrolnik, K.; Corrêa, G.R. Phosphorous forms in cultivated indian black earth (anthrosols) of varying texture in the brazilian Amazon. Rev. Bras. Cienc. Solo 2009, 33, 1347-1355. [CrossRef]

35. Schaefer, C.E.G.R.; Lima, H.N.; Gilkes, R.J.; Mello, J.W.V. Micromorphology and electron microprobe analysis of phosphorus and potassium forms of an Indian Black Earth (IBE) Anthrosol from Western Amazonia. Aust. J. Soil Res. 2004, 42, 401-409. [CrossRef]

36. Sombroek, W. Amazon. Soils: A Reconnaissance of the Soils of the Brazilian Amazon Region; Centre for Agricultural Publications and Documentation: Wageningen, The Netherlands, 1966.

37. Sato, S.; Neves, E.G.; Solomon, D.; Liang, B.Q.; Lehmann, J. Biogenic calcium phosphate transformation in soils over millennial time scales. J. Soil Sediments 2009, 9, 194-205. [CrossRef]

38. Chamberlain, P.M.; Bull, I.D.; Black, H.I.J.; Ineson, P.; Evershed, R.P. Fatty acid composition and change in Collembola fed differing diets: Identification of trophic biomarkers. Soil Biol. Biochem. 2005, 37, 1608-1624. [CrossRef]

39. Amelung, W.; Brodowski, S.; Sandhage-Hofmann, A.; Bol, R. Combining Biomarker with Stable Isotope Analyses for Assessing the Transformation and Turnover of Soil Organic Matter; Sparks, D.L., Ed.; Elsevier: Burlington, MA, USA, 2008 ; Volume 100.

40. Mckey, D.; Rostain, S.; Iriarte, J.; Glaser, B.; Birk, J.J.; Holst, I.; Renard, D. Pre-Columbian agricultural landscapes, ecosystem engineers, and self-organized patchiness in Amazonia. Proc. Natl. Acad. Sci. USA 2010, 107, 7823-7828. [CrossRef] [PubMed]

41. Birk, J.J.; Teixeira, W.G.; Neves, E.G.; Glaser, B. Faeces deposition on Amazonian Anthrosols as assessed from 5 beta-stanols. J. Archaeol. Sci. 2011, 38, 1209-1220. [CrossRef]

42. Birk, J.J.; Dippold, M.; Wiesenberg, G.L.; Glaser, B. Combined quantification of faecal sterols, stanols, stanones and bile acids in soils and terrestrial sediments by gas chromatography-mass spectrometry. J. Chromatogr. A 2012, 1242, 1-10. [CrossRef]

43. Lombardo, U.; Szabo, K.; Capriles, J.M.; May, J.H.; Amelung, W.; Hutterer, R.; Lehndorff, E.; Plotzki, A.; Veit, H. Early and middle holocene hunter-gatherer occupations in western Amazonia: The hidden shell middens. PLoS ONE 2013, 8, e72746. [CrossRef]

44. Glaser, B.; Birk, J.J. State of the scientific knowledge on properties and genesis of Anthropogenic Dark Earths in Central Amazonia (terra preta de Indio). Geochim. Cosmochim. Acta 2012, 82, 39-51. [CrossRef] 
45. Glaser, B.; Haumaier, L.; Guggenberger, G.; Zech, W. Black carbon in Terra Preta and Oxisols of the Brazilian Amazon as estimated by benzenecarboxylic acids as specific markers. Abstr. Pap. Am. Chem. Soc. 1999, 217, U829.

46. Glaser, B.; Balashov, E.; Haumaier, L.; Guggenberger, G.; Zech, W. Black carbon in density fractions of anthropogenic soils of the Brazilian Amazon region. Org. Geochem. 2000, 31, 669-678. [CrossRef]

47. Novotny, E.H.; Hayes, M.H.B.; Madari, B.E.; Bonagamba, T.J.; deAzevedo, E.R.; de Souza, A.A.; Song, G.X.; Nogueira, C.M.; Mangrich, A.S. Lessons from the Terra Preta de Indios of the Amazon Region for the utilisation of charcoal for soil amendment. J. Braz. Chem. Soc. 2009, 20, 1003-1010. [CrossRef]

48. Glaser, B.; Haumaier, L.; Guggenberger, G.; Zech, W. Black carbon in soils: The use of benzenecarboxylic acids as specific markers. Org. Geochem. 1998, 29, 811-819. [CrossRef]

49. Brodowski, S.; Rodionov, A.; Haumaier, L.; Glaser, B.; Amelung, W. Revised black carbon assessment using benzene polycarboxylic acids. Org. Geochem. 2005, 36, 1299-1310. [CrossRef]

50. Kappenberg, A.; Blasing, M.; Lehndorff, E.; Amelung, W. Black carbon assessment using benzene polycarboxylic acids: Limitations for organic-rich matrices. Org. Geochem. 2016, 94, 47-51. [CrossRef]

51. Schneider, M.P.W.; Lehmann, J.; Schmidt, M.W.I. Charcoal quality does not change over a century in a tropical agro-ecosystem. Soil Biol. Biochem. 2011, 43, 1992-1994. [CrossRef]

52. Wolf, M.; Lehndorff, E.; Wiesenberg, G.L.B.; Stockhausen, M.; Schwark, L.; Amelung, W. Towards reconstruction of past fire regimes from geochemical analysis of charcoal. Org. Geochem. 2013, 55, 11-21. [CrossRef]

53. Glaser, B.; Woods, W.I. Amazonian Dark Earths: Explorations in Space and Time; Springer: Berlin/Heidelberg, Germany, 2004.

54. Parsons, J.W. Chemistry and distribution of amino sugars in soils and soil organisms. In Soil Biochemistry; Paul, E.A., Ladd, J.N., Eds.; Marcel Dekker: New York, NY, USA, 1981; Volume 5, pp. 197-227.

55. Amelung, W. Methods using amino sugars as markers for microbial residues in soil. In Assessment Methods for Soil Carbon; Lewis Publishers: Boca Raton, FL, USA, 2001; Volume 100, pp. 233-270.

56. Liang, C.; Amelung, W.; Lehmann, J.; Kästner, M. Quantitative assessment of microbial necromass contribution to soil organic matter. Glob. Chang. Biol. 2019, 25, 3578-3590. [CrossRef] [PubMed]

57. Denevan, W.M. A bluff model of riverine settlement in prehistoric Amazonia. Ann. Assoc. Am. Geogr. 1996, 86, 654-681. [CrossRef]

58. Kern, D.C.; da Costa, M.L.; Frazão, F.J.L. Evolution of the scientific knowledge regarding archaeological black Earths of Amazonia. In Amazonian Dark Earths: Explorations in Space and Time; Glaser, B., Woods, W.I., Eds.; Springer: Berlin/Heidelberg, Germany, 2004.

59. Lips, J.M.; Duivenvoorden, J.F. Regional patterns of well drained upland soil differentiation in the middle Caquetá basin of Colombian Amazonia. Geoderma 1996, 72, 219-257. [CrossRef]

60. Duivenvoorden, J.F. Vascular plant species counts in the rain forests of the middle Caqueta area, Colombian Amazonia. Biodivers. Conserv. 1994, 3, 685-715. [CrossRef]

61. Tiessen, H.; Moir, J.O. Characterization of available P by sequential extraction. Can. Soc. Soil Sci. 1993, 7, 75-86.

62. Murphy, J.; Riley, J.P. A modified single solution method for the determination of phosphate in natural waters. Anal. Chim. Acta 1962, 27, 31-36. [CrossRef]

63. Kappenberg, A.; Lehndorff, E.; Pickarski, N.; Litt, T.; Amelung, W. Solar controls of fire events during the past 600,000 years. Quat. Sci. Rev. 2019, 208, 97-104. [CrossRef]

64. Zhang, X.; Amelung, W. Gas chromatographic determination of muramic acid, glucosamine, mannosamine, and galactosamine in soils. Soil Biol. Biochem. 1996, 28, 1201-1206. [CrossRef]

65. Amelung, W.; Lobe, I.; Du Preez, C.C. Fate of microbial residues in sandy soils of the South African Highveld as influenced by prolonged arable cropping. Eur. J. Soil Sci. 2002, 53, 29-35. [CrossRef]

66. Kunz, S. Stickstoff-Pools Tropischer Böden: Eine Vergleichende Studie von Oxisol und Terra Preta do Indio (Indianerschwarzerden); Martin Luther University Halle-Wittenberg: Halle, Germany, 1996.

67. Glaser, B.; Zech, W.; Woods, W.I. History, current knowledge and future perspectives of geoecological research concerning the origin of Amazonian anthropogenic Dark Earths (Terra Preta). In Amazonian Dark Earths: Explorations in Space and Time; Glaser, B., Woods, W.I., Eds.; Springer: Berlin/Heidelberg, Germany, 2004; pp. 9-18.

68. Lima, H.N.; Schaefer, C.E.R.; Mello, J.W.V.; Gilkes, R.J.; Ker, J.C. Pedogenesis and pre-Colombian land use of “Terra Preta Anthrosols" ("Indian black earth") of Western Amazonia. Geoderma 2002, 110, 1-17. [CrossRef]

69. Harrison, X.A.; Donaldson, L.; Correa-Cano, M.E.; Evans, J.; Fisher, D.N.; Goodwin, C.E.D.; Robinson, B.S.; Hodgson, D.J.; Inger, R. A brief introduction to mixed effects modelling and multi-model inference in ecology. Peer] 2018, 6, e4794. [CrossRef]

70. Falcão, N.P.S.; Clement, C.R.; Tsai, S.M.; Comerford, N.B. Pedology, fertility, and biology of central Amazonian Dark Earths. In Amazonian Dark Earths: Wim Sombroek's Vision; Woods, W.I., Teixeira, W.G., Lehmann, J., Steiner, C., Winkler Prins, A., Rebellato, L., Eds.; Springer: Dordrecht, The Netherlands, 2009; pp. 213-228.

71. Novotny, E.H.; Hayes, M.H.B.; deAzevedo, E.R.; Bonagamba, T.J. Characterisation of black carbon-rich samples by C-13 solid-state nuclear magnetic resonance. Naturwissenschaften 2006, 93, 447-450. [CrossRef]

72. Totsche, K.U.; Amelung, W.; Gerzabek, M.H.; Guggenberger, G.; Klumpp, E.; Knief, C.; Lehndorff, E.; Mikutta, R.; Peth, S.; Prechtel, A.; et al. Microaggregates in soils. J. Plant Nutr. Soil Sci. 2018, 181, 104-136. [CrossRef]

73. Turner, B.L.; Condron, L.M.; Richardson, S.J.; Peltzer, D.A.; Allison, V.J. Soil organic phosphorus transformations during pedogenesis. Ecosystems 2007, 10, 1166-1181. [CrossRef] 
74. Zhang, Q.; Bol, R.; Amelung, W.; Missong, A.; Siemens, J.; Mulder, I.; Willbold, S.; Müller, C.; Westphal Muniz, A.; Klumpp, E. Water dispersible colloids and related nutrient availability in Amazonian Terra Preta soils. Geoderma 2020, $97,115103$.

75. Lang, F.; Pohlmeier, A.; Kaupenjohann, M. Mechanism of molybdenum sorption to iron oxides using pressure-jump relaxation. J. Plant Nutr. Soil Sci. 2000, 163, 571-575. [CrossRef]

76. Alho, C.F.B.V. Long-Term Persistence of Soil Organic Matter in Amazonian Dark Earth. Ph.D. Thesis, Embrapa SolosTese/Dissertação (ALICE). 2019. Available online: https://www.alice.cnptia.embrapa.br/handle/doc/1114989 (accessed on 23 June 2021).

77. Rumpel, C.; Kögel-Knabner, I. Deep soil organic matter-A key but poorly understood component of terrestrial C cycle. Plant Soil 2011, 338, 143-158. [CrossRef] 